\title{
LAJU PERTUMBUHAN, MORTALITAS, REKRUTMEN, EKSPLOITASI STOK IKAN, DOMINAN, DAN TOTAL HASIL TANGKAPAN IKAN DI DANAU TONDANO, SULAWESI UTARA
}

\author{
Endi Setiadi Kartamihardja
}

\begin{abstract}
ABSTRAK
Danau Tondano dengan luas 4.700 ha merupakan perairan dengan tingkat kesuburan tinggi sehingga potensial untuk pengembangan perikanan tangkap. Penelitian pengkajian stok ikan dominan yakni ikan payangka (Ophiocara porocephala); mujair (Oreochromis mossambicus), dan gabus (Channa striata) telah dilakukan dari bulan Juni 1997 sampai dengan Maret 1998. Survai perikanan dilakukan untuk mencatat data frekuensi panjang ikan, jumlah hasil tangkapan, jenis alat tangkap, dan jumlah nelayan. Pencatatan dilakukan oleh enumerator di tempat pendaratan ikan setiap pekan selama sepuluh bulan. Laju pertumbuhan, mortalitas, rekrutmen, dan laju eksploitasi stok ikan dianalisis menggunakan paket program FiSAT. Parameter pertumbuhan Von Bertalanffy, $L ¥$, dan $K$ untuk ikan payangka, mujair, dan gabus masing-masing berturut-turut adalah $23,4 \mathrm{~cm}$ dan $1,1 \mathrm{th}^{-1} ; 24,9 \mathrm{~cm}$ dan $1,0 \mathrm{th}^{-1} ; 45,7 \mathrm{~cm}$ dan $1,1 \mathrm{th}^{-1}$. Pola rekrutmen stok ikan pada umumnya menunjukkan dua puncak rekrutmen dalam setahun. Tingkat eksploitasi stok ikan payangka dan mujair ( $E=0.55$ dan 0.53 ) berada sedikit di atas tingkat eksploitasi optimumnya. Dugaan total hasil tangkapan ikan adalah sebesar 507,6 ton per tahun atau rata-rata $108 \mathrm{~kg} / \mathrm{ha} / \mathrm{th}$ dengan potensi hasil ikan sebesar $164 \mathrm{~kg} / \mathrm{ha} / \mathrm{th}$. Total hasil tangkapan dapat ditingkatkan melalui perbaikan struktur komunitas ikannya
\end{abstract}

ABSTRACT: Growth, mortality, recruitment, exploitation rate of dominant fish stocks, and yield of fish in Tondano Lake, North Sulawesi. By: Endi Setiadi Kartamihardja

Tondano Lake with a water surface area of 4,700 ha is classified as eutrophic waters being potential for fish capture development. An assessment of some dominant fish stocks, namely Ophiocara porocephala; Oreochromis mossambicus; and Channa striata has been conducted from June 1997 to March 1998. Catch assessment surveys at fish landing sites were carried out every week for ten months. Length-based methods for fish population parameters were adopted. Length frequency data were analyzed using FiSAT program. Von Bertalanffy growth parameters, $L ¥$, and $K$ of $O$. porocephala; O. mossambicus, and $C$. striata were $23.4 \mathrm{~cm}$ and $1.1 \mathrm{yr} \mathrm{r}^{1} ; 24.9 \mathrm{~cm}$ and $1.0 \mathrm{yr}^{-1} ; 45.7 \mathrm{~cm}$ and $1.1 \mathrm{yr}^{-1}$, respectively. Recruitment patterns of these dominant fish stocks showed two to three peaks of recruitment. Exploitation rates of 0 . porocephala and 0 . mossambicus stocks ( $E=0.55$ and 0,53$)$ were considered exceed the optimum level. The fish yield of the Tondano Lake was estimated to be around $507.6 \mathrm{mt}$ annually or $108 \mathrm{~kg} / \mathrm{ha} / \mathrm{yr}$ with the fish yield potential of $164 \mathrm{~kg} / \mathrm{ha} / \mathrm{yr}$. The total fish yield could be increased through improvement of fish community structure

KEYWORDS: growth, mortality, recruitm ent, exploitation, yield, fish stock, lake

\section{PENDAHULUAN}

Danau Tondano yang luasnya sekitar 4.700 ha dengan kedalaman rata-rata $16 \mathrm{~m}$ termasuk perairan dengan kesuburan sedang sampai tinggi (Krismono \& Umar, 1998). Di perairan ini berkembang usaha perikanan tangkap dan usaha budi daya ikan dalam keramba jaring apung. Usaha penangkapan ikan dilakukan oleh tidak kurang dari 1.000 orang nelayan. Di danau ini hidup sebanyak 13 jenis ikan yang sebagian besar adalah ikan introduksi (exotic species) yang dilakukan sejak tahun 1851 (Whitten et al., 1987). Jenis ikan yang potensial untuk dikembangkan di perairan ini adalah ikan payangka (Ophiochara porocephala), ikan mujair (Oreochromis mossambicus) sebagai ikan introduksi dan ikan gabus (Channa striata) sebagai ikan asli (indigenous species) (Kartamihardja et al., 1999). Populasi ikan di perairan ini dilaporkan cenderung menurun dan ukuran tiap jenisnya mulai mengecil.

Tujuan pengelolaan perikanan di suatu perairan adalah untuk meningkatkan produksi ikan dan memeliharanya pada tingkat hasil yang stabil mendekati produksi optimumnya. Untuk optimalisasi

Peneliti pada Balai Penelitian Perikanan Air Tawar 
pemanfaatan sumber daya ikan tersebut, diperlukan suatu strategi pengelolaan yang didasarkan kepada data dan informasi ilmiah. Informasi ilmiah penting untuk keperluan tersebut meliputi aspek biologis, sosial ekonomis dan kelembagaan. Dalam aspek biologis, data dan informasi yang terpenting adalah mengenai dinamika stok ikan yang meliputi struktur komunitas, biologi reproduksi, pertumbuhan, mortalitas, rekrutmen, dan besaran stok ikan. Data struktur komunitas ikan dan reproduksi beberapa jenis ikan dominan di danau ini telah tersedia (Kartamihardja et al. 1999). Dalam suatu populasi ikan yang tertutup (tidak ada migrasi dan emigrasi), faktor utama yang mempengaruhi peningkatan stok adalah pertumbuhan dan rekrutmen sedangkan faktor yang mempengaruhi penurunan stok ikan adalah mortalitas alami dan penangkapan. Dengan demikian. data dan informasi mengenai pertumbuhan, rekrutmen dan mortalitas stok ikan adalah faktor utama yang harus diketahui untuk keperluan pengelolaan populasi ikan di suatu perairan.

Tujuan penelitian ini adalah untuk menduga parameter populasi ikan yang meliputi laju pertumbuhan, mortalitas, pola rekrutmen, relatif hasil dan biomassa per rekrutmen dan laju eksploitasi ikan yang mendominasi hasil tangkapan nelayan serta menduga total hasil tangkapan nelayan. Data dan informasi yang diperoleh diharapkan dapat digunakan dalam menentukan pola pengelolaan dan pengembangan sumber daya perikanan di perairan tersebut secara optimum dan lestari.

\section{BAHAN DAN METODE}

\section{Cara Pengumpulan Data}

Pengumpulan data dilakukan melalui survai perikanan. Data yang dikumpulkan terdiri atas data komposisi, distribusi frekuensi panjang, dan kelimpahan relatif stok ikan dari kegiatan penangkapan yang dilakukan nelayan setempat. Selain itu dilakukan pula pencatatan jumlah nelayan, jumlah dan jenis alat tangkap (gillnet dan jala), lama operasi penangkapan, bobot hasil tangkapan, dan komposisi jenis ikannya. Data tersebut dicatat oleh enumerator di empat tempat pendaratan ikan setiap minggu selama 10 bulan mulai Juni 1997 sampai dengan Maret 1998. Dalam pengumpulan data tersebut dipertimbangkan mengenai akurasi dan kepentingannya seperti yang disarankan oleh Murray (1990)

\section{Pendugaan Parameter Pertumbuhan}

Pertumbuhan ikan dinyatakan dalam rumus pertumbuhan Von Bertalanffy (VBGF) sebagai berikut:

$$
L t=L ¥\left\{1-e^{-K(t-t o)}\right\}
$$

di mana

$L_{t}=$ prediksi panjang pada umur $t$

$L ¥=$ rata-rata panjang asimptotik

$\mathrm{K}=$ konstanta pertumbuhan

$\mathrm{t}_{0}=$ umur hipotesis ikan pada panjang nol

Parameter pertumbuhan Von Bertalanffy $L ¥$ pertama kali diduga menggunakan modifikasi dari Wetherall Plot. Data frekuensi panjang tiap jenis ikan dijumlahkan dan kemudian digunakan untuk menduga $L ¥$ and $Z / K$. Kemudian $L ¥$ dipakai untuk menduga parameter pertumbuhan Von Bertalanffy menggunakan program ELEFAN I (Gayanilo et al. 1988) sebagai bagian dari program FiSAT (Gayanilo et al., 1994).

\section{Pendugaan Mortalitas}

Mortalitas total (Z) dari stok ikan diduga menggunakan program FiSAT (Gayanilo et al., 1994), dan dugaan $\mathbf{Z}$ diperoleh dari kurva tangkapan sebagai refleksi dari konversi panjang (lengthconverted catch curve) seperti yang diuraikan dalam Pauly (1983a, 1984a, 1984b).

Dugaan mortalitas alami (M) dari stok ikan dihitung menggunakan persamaan Pauly (Pauly, 1980) sebagai berikut

\section{$\log M=-0.0066-0.279 \log \mathrm{Z}+0.6543 \log K+$ $0.4634 \log T$}

di mana $T$ adalah rata-rata tahunan suhu perairan $\left(27,0^{\circ} \mathrm{C}\right)$ danau Tondano. Kemudian mortalitas penangkapan $(\mathrm{F})$ dihitung dari persamaan $\mathrm{F}=\mathrm{Z}-\mathrm{M}$.

\section{Pendugaan Laju Eksploitasi}

Setelah nilai mortalitas penangkapan ( $F)$ diketahui, maka laju eksploitasi (E) dihitung dari persamaan $E=F / Z$. Dengan asumsi bahwa nilai optimum $F$ dari stok ikan yang dieksploitasi $\left(F_{\text {oot }}\right)$ adalah sebanding dengan mortalitas alaminya (M) maka eksploitasi optimum ( $E_{\text {opt }}$ ) yang diharapkan adalah sama dengan 0.5 (Gulland, 1971).

\section{Pendugaan Pola Rekrutmen}

Pola rekrutmen diperoleh dengan memproyeksikan data frekuensi panjang terhadap 
waktu dengan menggunakan parameter pertumbuhan (Pauly, 1982). Hasil tangkapan relatif per rekrutmen $(Y / R)$ dan biomassa relatif per rekrutmen ( $B / R$ ) diduga menggunakan model Beverton dan Holt yang dimodifikasi oleh Pauly \& Soriano (1986).

\section{Pendugaan Hasil Tangkapan}

Dugaan hasil tangkapan ikan bulanan pada periode tahun 1997-1998 dihitung dari data yang dikumpulkan di empat tempat pendaratan ikan oleh enumerator selama 10 bulan pengamatan dengan menggunakan persamaan Williams (1977), sebagai berikut:

$$
Y_{j}=S N_{i} \times S C_{i k} / n_{i}
$$

dengan

$Y_{j}=$ dugaan hasil tangkapan dalam bulan $\mathrm{ke}-\mathrm{j}$

$\mathrm{C}_{\mathrm{ik}}=$ tangkapan nelayan $\mathrm{k}$ di tempat pendaratan $\mathrm{i}$

$n=$ jumlah sampel nelayan di tempat pendaratan $i$

$N_{i}=$ jumlah total nelayan di tempat pendaratan $i$

Berdasarkan rumusan tersebut hasil tangkapan total dalam satu tahun selama penelitian ini dihitung dengan menggunakan persamaan sebagai berikut:

dengan

$$
Y=S Y_{j}+2 \times Y_{j} / 10
$$

$Y=$ hasil tangkapan total dalam satu tahun dan

$Y_{j}=$ dugaan hasil tangkapan dalam bulan $k e j$.

\section{HASIL DAN BAHASAN}

Pengumpulan data hasil tangkapan nelayan di setiap lokasi penelitian yang dilakukan oleh enumerator berturut-turut selama 10 bulan pengamatan. Jenis ikan hasil tangkapan nelayan terdiri atas ikan payangka (Ophiocara porocephala), mujair (Oreochromis mossambicus), nila (Oreochromis niloticus), gabus (Channa striata), gurami (Osphronemus gouramy), sepat
(Trichogaster pectoralis), mas (Cyprinus carpio), nilem (Osteochilus hasselti), dan lele (Clarias batrachus). Jenis-jenis ikan yang mendominasi hasil tangkapan adalah ikan payangka, mujair, dan gabus. Data sebaran frekuensi panjang yang dianalisis untuk pendugaan parameter populasi terdiri atas jenis ikan yang mendominasi hasil tangkapan nelayan (Lampiran 1, 2, dan 3).

\section{Parameter Pertumbuhan}

Dugaan parameter pertumbuhan dari ikan payangka, mujair, dan gabus tertera pada Tabel 1 sedangkan kurva pertumbuhannya tertera pada Gambar 1.

Dugaan parameter pertumbuhan ikan payangka, mujair, dan gabus tersebut dapat dinyatakan dalam persamaan Von Bertalanffy sebagai berikut:

$$
\begin{array}{ll}
\text { payangka: } & \mathrm{Lt}=23.4\left\{1-\mathrm{e}^{-1.1(\mathrm{t}-\mathrm{to})}\right\} \\
\text { mujair: } & \mathrm{Lt}=24.9\left\{1-\mathrm{e}^{-10(t-10)}\right\} \\
\text { gabus: } & \mathrm{Lt}=45.7\left\{1-\mathrm{e}^{-11(t-t)}\right\}
\end{array}
$$

Laju pertumbuhan ikan mujair di Danau Tondano lebih rendah daripada laju pertumbuhan ikan mujair di Waduk Kedungombo (Kartamihardja, 1995) namun lebih tinggi dari pada laju pertumbuhan ikan mujair di Danau Toba (Kartamihardja, 1993b). Laju pertumbuhan ikan gabus di Danau Tondano lebih rendah dibandingkan dengan laju pertumbuhan ikan gabus di Waduk Kedungombo (Kartamihardja, 1993a). Hal ini antara lain diduga erat kaitannya dengan perbedaan rata-rata suhu air di kedua perairan tersebut di mana rata-rata suhu air di Danau Tondano $\left(27,0^{\circ} \mathrm{C}\right)$ lebih tinggi dari suhu air Danau Toba $\left(26,5^{\circ} \mathrm{C}\right)$ tetapi lebih rendah dari pada suhu air Waduk Kedungombo $\left(29,5^{\circ} \mathrm{C}\right)$. Disamping itu, Waduk Kedungombo termasuk perairan dengan kesuburan sedang sampai tinggi (meso-eutrofik), Danau Tondano termasuk perairan dengan kesuburan sedang (mesotrofik) dan Danau Toba termasuk perairan miskin hara (oligotrofik). Tingkat kesuburan perairan tersebut berkorelasi positif terhadap kelimpahan planktonnya. Kelimpahan plankton di Waduk Kedungombo berkisar antara 10.235-12.367

Tabel 1.Dugaan parameter pertumbuhan stok ikan dominan di Danau Tondano Table 1. Estimated growth parameters of dominant fish stocks in Tondano Lake

\begin{tabular}{lcc}
\hline \multicolumn{1}{c}{ Jenis ikan/Fish species } & L8 (cm) & K (yr $\left.{ }^{1}\right)$ \\
\hline Payangka, O. porocephala & $23.4 \pm 0.4$ & $1.1 \pm 0.2$ \\
Mujair, O. mossambicus & $24.9 \pm 0.5$ & $1.0 \pm 0.2$ \\
Gabus, C. striata & $45.7 \pm 0.5$ & $1.1 \pm 0.2$ \\
\hline
\end{tabular}



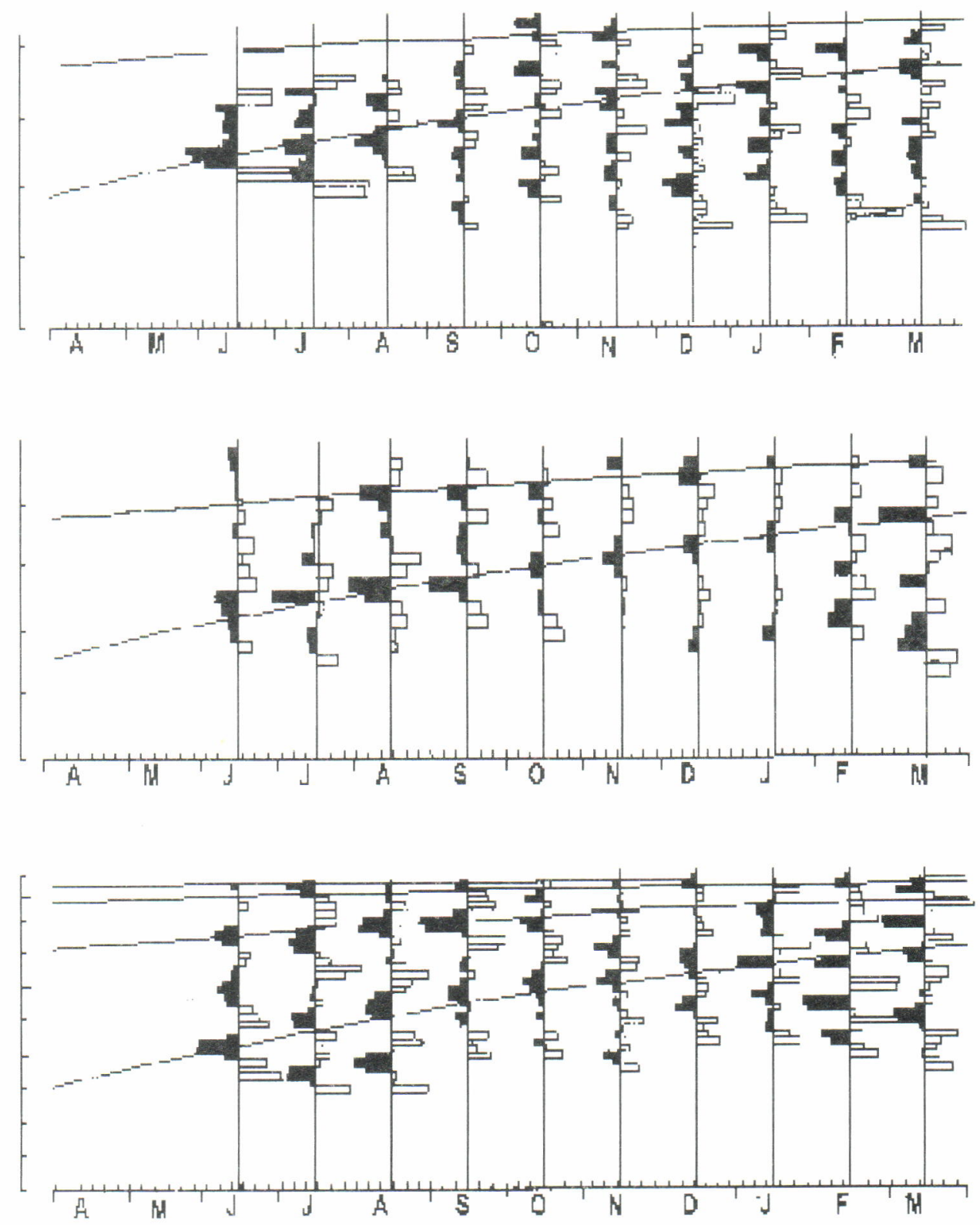

Gambar 1. Kurva pertumbuhan ikan payangka (A), mujair (B), dan ikan gabus (C) super-impose terhadap frekuensi panjangnya

Figure 1. Growth curve of O. porocephala (A), O. mossambicus (B), and C. striata (C) superimposed to their length frequency

Tabel 2. Dugaan mortalitas dan laju eksploitasi stok ikan di Danau Tondano

Table 2. Estimated mortality and exploitation rate of the dominant fish stocks in Tondano Lake

\begin{tabular}{lcccc}
\hline \multicolumn{1}{c}{ Jenis ikan/Fish species } & $\mathrm{Z}\left(\mathrm{yr}^{1}\right)$ & $\mathrm{K}\left(\mathrm{yr}^{1}\right)$ & $\mathrm{F}\left(\mathrm{yr}^{1}\right)$ & $\mathrm{E}=\mathrm{F} / \mathbf{Z}$ \\
\hline Payangka, O. porocephala & 4.13 & 1.85 & 2.28 & 0.55 \\
Mujair, O. mossambicus & 2.95 & 1.38 & 1.57 & 0.53 \\
Gabus, C. Striata & 2.06 & 1.08 & 0.98 & 0.48 \\
\hline
\end{tabular}


O. porocephala: $\ln (\mathrm{N} / \mathrm{Dt})=11.97-4.13(\mathrm{t}-\mathrm{to}) ; \mathrm{r}=0.957$

O. mossambicus: In (N/Dt) $=11.38-2.95$ (t-to); $r=0.99$

C. striatus: $\ln (\mathrm{N} / \mathrm{Dt})=10.06-2.06(\mathrm{t}-\mathrm{to}) ; \mathrm{r}=0.98$
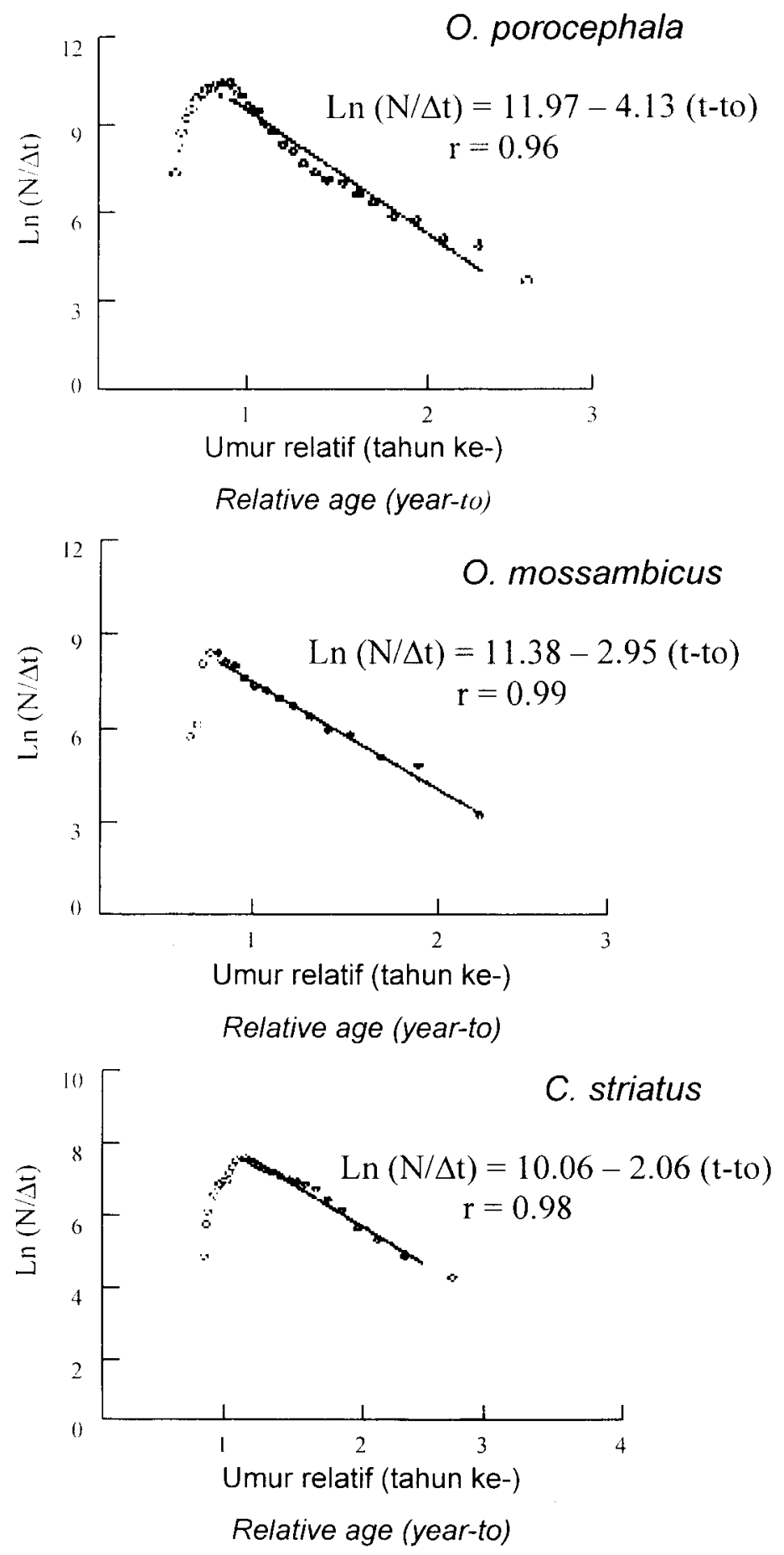

Gambar 2. Kurva tangkapan stok ikan payangka, mujair dan gabus di Danau Tondano Figure 2. Catch curves of payangka, java tilapia and snake head stocks in Tondano Lake 

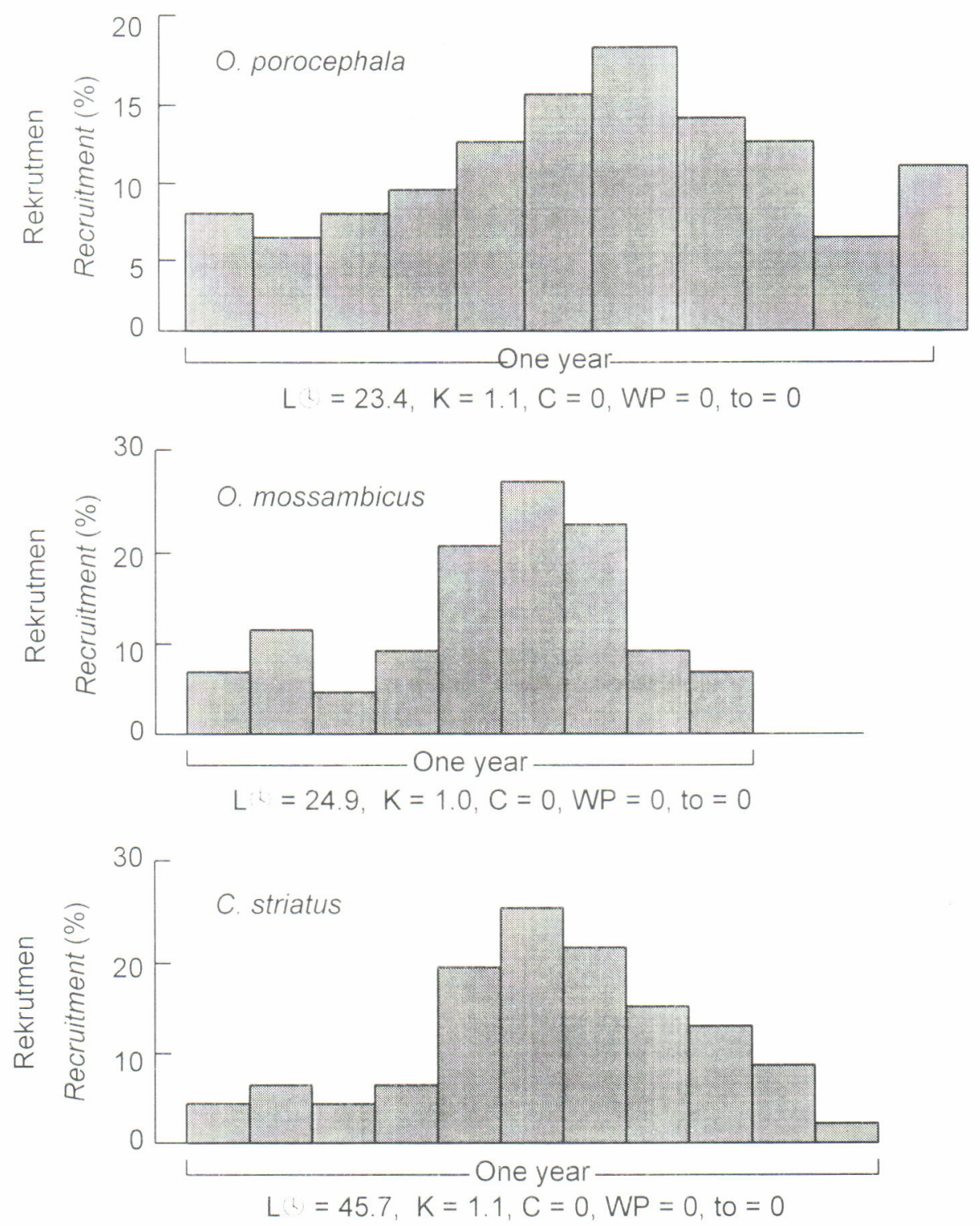

Gambar 3. Pola rekrutmen stok ikan payangka, mujair, dan gabus di Danau Tondano

Figure 3. Recruitment patterns of payangka, java tilapia and snake head in Tondano Lake

individu/L (Krismono \& Kartamihardja, 1995); di Danau Tondano 6.756-9.235 individu/L (Krismono \& Umar, 1998), dan di Danau Toba 293-1855 individu/ L (Tjahjo et al., 1998). Kelimpahan plankton ini akan berpengaruh terhadap laju pertumbuhan ikan mujair karena ikan tersebut termasuk ikan pemakan plankton (plankton feeder)

\section{Mortalitas dan Laju Eksploitasi}

Mortalitas total (Z), mortalitas alami (M) dan mortalitas penangkapan ( $F$ ) untuk masing-masing stok ikan tertera pada Tabel 2., sedangkan kurva tangkapannya tertera pada Gambar 2. Mortalitas alami stok ikan dihitung secara empiris dengan menggunakan rata-rata suhu air tahunan Danau Tondano yaitu $27,0^{\circ} \mathrm{C}$

Laju eksploitasi stok ikan payangka dan ikan mujair ( $E=0.55$ dan 0.53) menunjukkan nilai yang berada sedikit di atas laju eksploitasi optimumnya. Eksploitasi kedua stok ikan tersebut perlu diatur antara lain dengan membatasi jumlah alat tangkap yang digunakan. Laju eksploitasi stok ikan mujair tersebut sama dengan laju eksploitasi stok ikan mujair baik di Waduk Kedungombo, Jawa Tengah (Kartamihardja, 1993a) maupun di Danau Toba, Sumatera Utara (Kartamihardja, 1993b). Dengan 

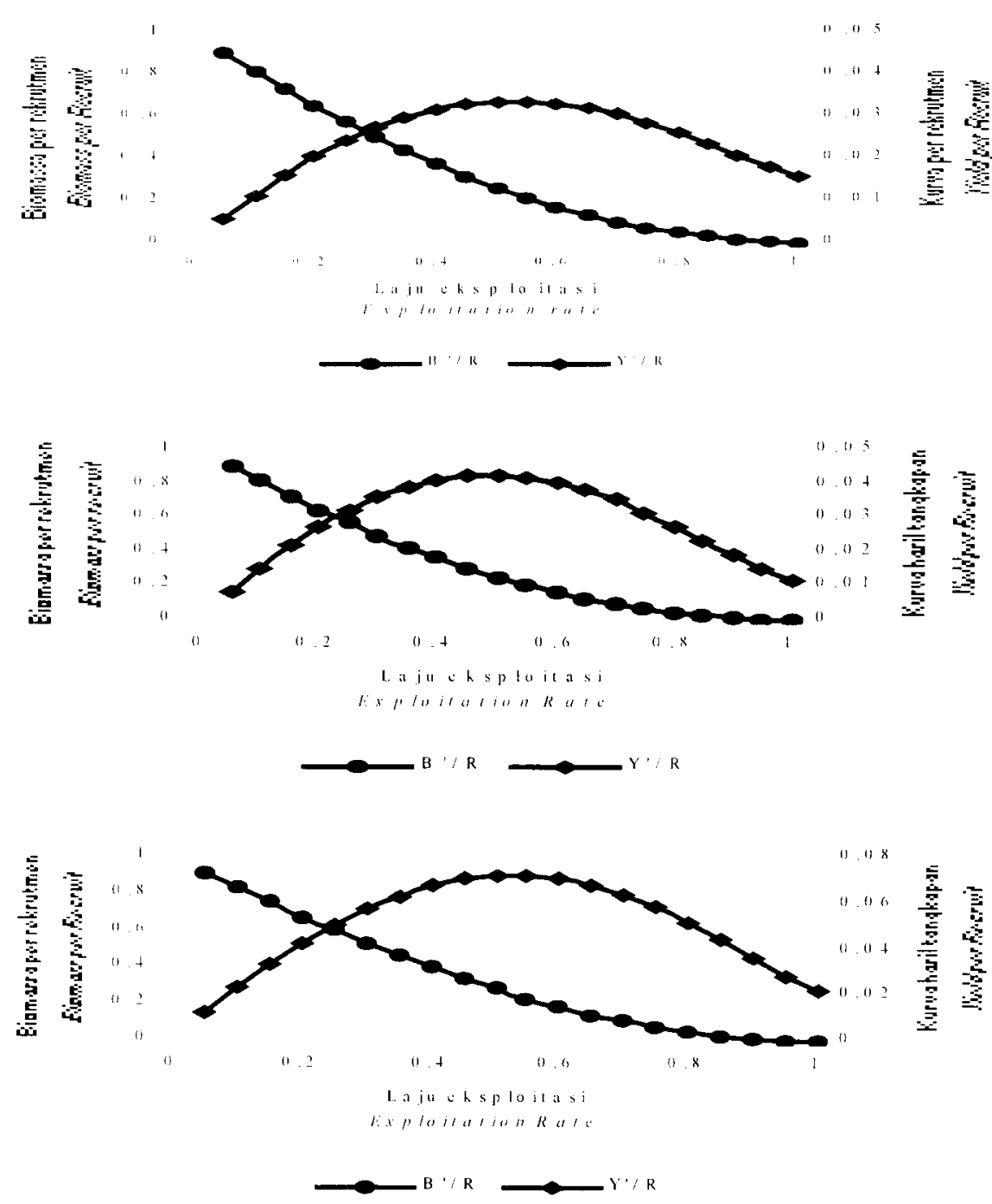

Gambar 4. Kurva hasil tangkapan dan biomas per rekrutmen stok ikan payangka (A), mujair (B), dan gabus (C) di Danau Tondano

Figure 4. Yield and biomass per recruit of payangka (A), java tilapia(B) and snake head (C) stocks in Tondano Lake

demikian laju penangkapan ikan payangka dan mujair di Danau Tondano dapat digolongkan pada tingkat eksploitasi yang intensif. Untuk mempertahankan tingkat eksploitasi yang tinggi dapat dilakukan upaya penebaran ulang (restocking) ikan secara berkala sehingga menambah rekrutmennya. Upaya penebaran ini hanya dapat dilakukan apabila benih ikannya mudah diperoleh dan jumlahnya cukup. Oleh karena itu, penebaran ikan di Danau Tondano yang paling memungkinkan untuk dilakukan adalah dengan ikan mujair atau nila. Penebaran ikan payangka akan sulit dilakukan karena jenis ikan tersebut belum dapat dibudidayakan sehingga benihnya masih tergantung dari produksi secara alami.

\section{Pola Rekrutmen}

Pola rekrutmen dari masing-masing stok ikan payangka, mujair, dan gabus tertera pada Gambar 3. Stok ikan mujair dan gabus menunjukkan dua puncak rekrutmen dalam setahun sedangkan ikan payangka menunjukkan tiga puncak rekrutmen dalam setahun. Hal ini menggambarkan bahwa stok ikan tersebut melakukan pemijahan lebih dari satu kali dalam setahun.

Hasil tangkapan dan biomas relatif per rekrutmen masing-masing stok ikan tertera pada Gambar 4. Dari gambar tersebut terlihat bahwa eksploitasi maksimum (Emax) stok ikan payangka, mujair dan gabus berturut-turut adalah 0,$49 ; 0,47$ dan 0,51 . Hal ini berarti bahwa jika laju eksploitasi ketiga stok ikan 


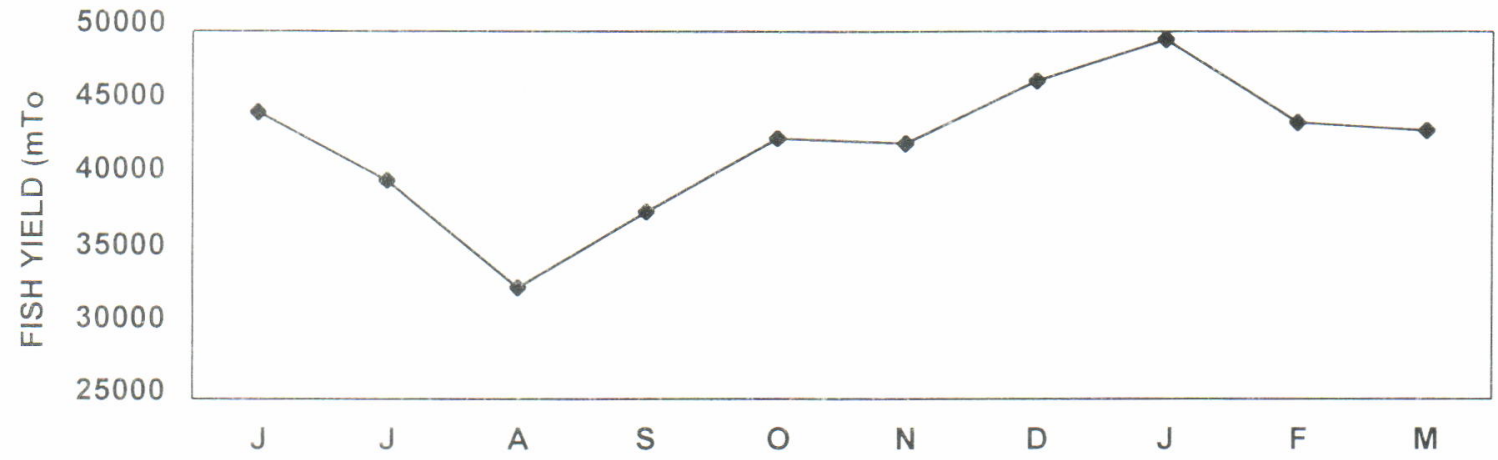

Gambar 5. Estimasi hasil tangkapan bulanan ikan di Danau Tondano pada Juni 1997-Maret 1998

Figure 5. Estimated monthly total fish yield in Tondano Lake in June 1997-March 1998

tersebut melebihi nilai eksploitasi maksimumnya maka untuk menjaga kelestariannya perlu dilakukan pengaturan pembatasan upaya penangkapannya

\section{Hasil Tangkapan Ikan}

Hasil tangkapan ikan bulanan pada periode tahun 1997-1998 di danau Tondano berkisar antara 32.650 $-49.487 \mathrm{~kg}$ dengan rata-rata $42.300 \pm 865 \mathrm{~kg}$. Hasil tangkapan terendah dicapai pada bulan Agustus 1997 dan tertinggi pada bulan Januari 1998 (Gambar 5).

Berdasarkan rata-rata hasil tangkapan ikan bulanan tersebut, total tangkapan ikan per tahun adalah 507,6 ton atau rata-rata $108 \mathrm{~kg} / \mathrm{ha} / \mathrm{th}$. Jika dibandingkan dengan hasil tangkapan ikan dari perairan waduk dan danau di Indonesia yang berkisar antara $15-380 \mathrm{~kg} / \mathrm{ha} / \mathrm{th}$ dengan rata-rata $177 \mathrm{~kg} / \mathrm{ha} /$ th (Sukadi \& Kartamihardja, 1994), maka hasil tangkapan ikan di Danau Tondano masih berada di bawah rata-rata. Hal ini diduga sangat erat hubungannya dengan belum optimalnya pemanfaatan relung ekologis (ecological niche) yang tersedia oleh jenis-jenis ikan yang ada. Di samping itu, pengelolaan sumber dayanya belum dilakukan secara optimal. Potensi hasil ikan Danau Tondano yang dihitung dari produktivitas primernya diperkirakan sebesar $164 \mathrm{~kg} / \mathrm{ha}$ /th (Kartamihardja et al., 1999). Total hasil tangkapan ikan yang dicapai sebenarnya masih di bawah potensi lestarinya, karena dengan menetapkan total maksimum ikan yang boleh ditangkap (total allowable catch, TAC) sebesar $80 \%$ dari potensi maksimum lestarinya, maka akan diperoleh produksi sebesar $156 \mathrm{~kg} / \mathrm{ha} /$ th. Namun karena eksploitasi stok ikan payangka dan mujair telah optimum maka peningkatan produksi harus dilakukan melalui upaya perbaikan struktur komunitas ikannya, sehingga relung ekologis yang kosong dapat dimanfaatkan secara optimum. Untuk keperluan tersebut, perlu dipertimbangkan penebaran ikan nila (Oreochromis niloticus) yang ditujukan untuk memanfaatkan plankton dan ikan tawes (Barbodes gonionotus) untuk memanfaatkan makrofita yang kelimpahannya cukup tinggi. Ikan nila yang ditebarkan dapat bersaing dengan ikan mujair dalam hal makanan dan habitat pemijahannya karena kebiasaan makanannya yang bersifat pemakan plankton dan sifat reproduksinya yang "mouth breeder" adalah sama. Penebaran ikan nila ini diharapkan akan menggantikan stok ikan mujair dengan alasan beberapa keunggulan yang dimilikinya yaitu ikan nila berukuran relatif lebih besar, pertumbuhannya lebih cepat dan harganya lebih mahal dari ikan mujair. Ikan tawes yang ditebarkan tidak akan berkompetisi dengan jenis ikan lainnya dalam hal pemanfaatan pakan ataupun habitat pemijahannya karena sampai saat ini di Danau Tondano tidak terdapat jenis ikan lain yang mempunyai kebiasaan makan dan reproduksi yang sama dengan ikan tawes.

\section{KESIMPULAN}

1. Dugaan parameter pertumbuhan, L: , dan K untuk ikan payangka, mujair, dan gabus masing-masing berturut-turut adalah $23,4 \mathrm{~cm}$ dan 1,1 th- $^{-1} ; 24,9$ $\mathrm{cm}$ dan $1,0 \mathrm{th}^{-1} ; 45,7 \mathrm{~cm}$ dan $1,1 \mathrm{th}^{-1}$.

2. Pola rekrutmen stok ikan payangka, mujair, dan gabus menunjukkan dua puncak rekrutmen dalam setahun yang erat hubungannya dengan pola pemijahannya.

3. Laju eksploitasi stok ikan payangka dan mujair menunjukkan sudah berada sedikit di atas tingkat optimumnya sehingga usaha pengelolaan stok ikan tersebut perlu diatur melalui pembatasan tingkat eksploitasinya. 
4. Total hasil tangkapan ikan dapat ditingkatkan melalui perbaikan struktur komunitas ikannya. Untuk itu disarankan melakukan penebaran ikan nila dan tawes

\section{DAFTAR PUSTAKA}

Gayanilo, F.C.Jr., M. Suriano, and D. Pauly. 1988. A Draft Guide COMPLEAT ELEFAN Software Project 2: 65p. and 10 diskettes.

Gayanilo, F.C.Jr., P. Sparre, and D. Pauly. 1994. The FAO-ICLARM Stock assessment tools (FISAT) user guide. FAO Computerized Information Series (Fisheries). FAO, Rome. No. 7, 186p.

Kartamihardja, E.S. 1987. Potensi produksi dan pengelolaan perikanan di Danau Toba, Sumatera Utara. Bull. Penel. Perikanan Darat. Vol.6, No.1: 78 84

Kartamihardja, E.S. 1993b. Some aspects of the population dynamic of tilapia, Oreochromis mossambicus at Toba lake, North Sumatera. Fisheries Journal Garing, Fisheries Faculty and Alumna, Bung Hatta University, Padang. 2(1): 5-8p.

Kartamihardja, E.S., A.S. Sarnita, dan H. Satria. 1999. Karakteristik populasi ikan di Danau Tondano, Sulawesi Utara. Jurnal Penelitian Perikanan Indonesia, Vol. V, No.1:7-19

Krismono dan C. Umar. 1998. Limno-biologi Danau Tondano, Sulawesi Utara. Jurnal Penelitian Perikanan Indonesia, Vol 4, No, 4: 1-10

Krismono, A.S.N. dan E.S.Kartamihardja. 1995. Status trofik perairan Waduk Kedungombo, Jawa Tengah, sebagai dasar pengelolaan perikanannya. Jurnal Penelitian Perikanan Indonesia, Vol. 1, No. 3: 26-35

Murray, P.A. 1990. Collection of fish lengths for stock assessment in developing countries. NAIA. Vol. 18. 1. The ICLARM Quarterly. January 1995.

Pauly, D. 1980. On the Relationships between Natural Mortality, Growth Parameter, and Mean Environmental
Temperature in 1975 Fish Stocks. J. Cons. CIEM. 39(2): 175-92.

Pauly, D. 1982. Studying Single Species Dynamics in Multispecies Context. In D. Pauly and G.I. Murphy (eds.) Theory and Management of Tropical Fisheries ICLARM Conference Proceeding 9, Manila, pp.33-70

Pauly, D. 1983a. Length converted catch curves. A Powerfull Tool for Fisheries Research in the tropics (Part I). ICLARM. Fishbyte 1(2); 9-13

Pauly, D. 1993b. Some Simple Methods for the Assessment of Tropical Fish stocks. FAO. Tech. Pap., (234); 52p

Pauly, D. 1984a. Length converted catch curves. A powerfull tool for fisheries research in the tropics (Part II). Fishbyte 2(1): 17-19.

Pauly, D. 1984b. Length converted catch curves. A powerfull tool for fisheries research in the tropics (Part III). Fishbyte 2(3): 9-10

Pauly, D. and M.L. Suriano. 1986. Some practical extensions to beverton and holts's relative yield-perrecruit model. In J.L. MAclean, L. B. dizon and L. V. Hosillos (eds.) The First Asian Fisheries Forum. Asian Fish. Soc., Manila, Philippines, pp.491-495

Sukadi, M.F. and E. S. Kartamihardja, 1994. Present status of inland waters fisheries of Indonesia, IPFC Workshops on Inland Fisheries, FAO, Rome. 21p.

Tjahjo, D.W.H., A.S. Nastiti, K. Purnomo, E.S. Kartamihardja, dan A.S. Sarnita. 1998. Potensi sumber daya perikanan di Danau Toba, Sumatera Utara. Jurnal Penelitian Perikanan Indonesia, IV (1): $1-12$

Whitten, A.J., Mustafa, and G.S. Henderson. 1987. The Ecology of Sulawesi. Gadjah Mada University press, Yogyakarta. 235p

Williams, T. 1977. The Raw material of population dynamics. In J.A. Gulland (ed) Fish Population Dynamics. John Wiley \& Son, Ltd., pp.28-45. 
Lampiran 1. Distribusi frekuensi panjang(LM) ikan payangka, Ophiochara porocephala di Danau Tondano Appendix 1. Length frequency distribution of Ophiochara porocephala in Tondano Lake

\begin{tabular}{|c|c|c|c|c|c|c|c|c|c|c|}
\hline \multirow{2}{*}{$\begin{array}{l}\mathrm{LM} \\
(\mathrm{cm})\end{array}$} & \multicolumn{7}{|c|}{1997} & \multicolumn{3}{|c|}{1998} \\
\hline & $\mathbf{J}$ & $\mathrm{J}$ & $A$ & $S$ & 0 & $\mathbf{N}$ & D & $\mathbf{J}$ & $F$ & $M$ \\
\hline 6.5 & - & - & - & - & - & - & - & - & - & - \\
\hline 7.5 & - & - & - & 3 & - & 3 & - & - & - & - \\
\hline 8.5 & - & - & - & 5 & - & 2 & 2 & - & - & - \\
\hline 9.5 & - & - & - & 11 & - & 8 & 6 & 2 & - & - \\
\hline 10.5 & - & 1 & - & 8 & - & 1 & 6 & 3 & 1 & 4 \\
\hline 11.5 & - & 1 & & 15 & - & 15 & 23 & 12 & 9 & 10 \\
\hline 12.5 & 1 & 22 & 5 & 8 & 1 & 13 & 23 & 3 & 7 & 12 \\
\hline 13.5 & 1 & 17 & 1 & 16 & 3 & 33 & 42 & 34 & 22 & 15 \\
\hline 14.5 & 32 & 20 & 42 & 18 & 11 & 18 & 27 & 7 & 22 & 28 \\
\hline 15.5 & 15 & 19 & 9 & 18 & 10 & 29 & 21 & 40 & 26 & 33 \\
\hline 16.5 & 40 & 30 & 39 & 17 & 15 & 15 & 9 & 7 & 16 & 16 \\
\hline 17.5 & 12 & 5 & 5 & 22 & 30 & 22 & 10 & 34 & 38 & 12 \\
\hline 18.5 & 7 & 17 & 10 & 21 & 38 & 9 & 5 & 10 & 14 & 9 \\
\hline 19.5 & 4 & 3 & 1 & 9 & 37 & 8 & 8 & 23 & 16 & 4 \\
\hline 20.5 & 7 & 9 & 3 & 4 & 16 & 2 & 2 & 1 & 1 & 3 \\
\hline 21.5 & 1 & 2 & 1 & 4 & 14 & 4 & 4 & 4 & 11 & 8 \\
\hline 22.5 & 1 & 8 & 2 & 7 & 7 & 5 & 1 & 3 & 2 & 2 \\
\hline 23.5 & - & 2 & 1 & 7 & 1 & 6 & 4 & 5 & 5 & 2 \\
\hline 24.5 & - & 1 & 3 & - & 4 & 1 & 1 & 2 & 1 & 1 \\
\hline 25.5 & - & - & 1 & - & 2 & 1 & 1 & 4 & 3 & 1 \\
\hline 26.5 & - & - & - & - & 1 & 2 & - & 1 & 1 & - \\
\hline 27.5 & - & - & - & - & 2 & 1 & - & 4 & 3 & - \\
\hline 28.5 & - & - & - & - & 1 & 1 & - & 1 & 1 & - \\
\hline 29.5 & - & - & - & - & 1 & 1 & - & 1 & 1 & - \\
\hline 30.5 & - & - & - & - & - & 1 & - & - & - & - \\
\hline
\end{tabular}


Lampiran 2. Distribusi frekuensi panjang (LM) ikan mujair, Oreochromis mossambicus di Danau Tondano Appendix 2. Length frequency distribution of java tilapia, Oreochromis mossambicus in Tondano Lake

\begin{tabular}{|c|c|c|c|c|c|c|c|c|c|c|}
\hline \multirow{2}{*}{$\begin{array}{l}\mathrm{LM} \\
(\mathrm{cm})\end{array}$} & \multicolumn{7}{|c|}{1997} & \multicolumn{3}{|c|}{1998} \\
\hline & $\mathrm{J}$ & $\mathrm{J}$ & $A$ & $S$ & 0 & $\mathrm{~N}$ & D & $\mathrm{J}$ & $\mathrm{F}$ & $M$ \\
\hline 6,5 & - & - & - & - & - & - & 9 & 10 & - & - \\
\hline 7.5 & - & & - & - & - & - & 12 & 15 & 11 & - \\
\hline 8,5 & - & - & - & 14 & - & - & 147 & 30 & 7 & 20 \\
\hline 9,5 & - & 2 & 2 & 10 & 33 & 12 & 135 & 102 & 10 & 99 \\
\hline 10,5 & 1 & 4 & 3 & 7 & 16 & 48 & 121 & 233 & 41 & 117 \\
\hline 11,5 & 3 & 11 & 5 & 6 & 13 & 33 & 31 & 82 & 50 & 137 \\
\hline 12,5 & 7 & 15 & 7 & 3 & 7 & 5 & 17 & 29 & 32 & 121 \\
\hline 13,5 & 9 & 17 & 9 & 5 & 9 & 7 & 31 & 44 & 15 & 15 \\
\hline 14,5 & 5 & 23 & 17 & 7 & 10 & 11 & 12 & 12 & 24 & 17 \\
\hline 15,5 & 7 & 19 & 21 & 9 & 11 & 7 & 6 & 4 & 33 & 7 \\
\hline 16,5 & 6 & 12 & 17 & 11 & 15 & 5 & 1 & 7 & 6 & 2 \\
\hline 17,5 & 3 & 5 & 11 & 5 & 13 & 9 & 3 & 9 & 8 & 3 \\
\hline 18,5 & 1 & 7 & 2 & 1 & 6 & 11 & 7 & 11 & 9 & 1 \\
\hline 19,5 & 2 & 3 & 1 & 1 & 3 & 7 & 2 & 13 & 4 & 1 \\
\hline 20,5 & 1 & 5 & 1 & 2 & 2 & 4 & 3 & 6 & 3 & 1 \\
\hline 21,5 & 1 & 2 & 1 & 2 & 1 & 3 & 1 & 2 & 1 & 1 \\
\hline 22,5 & - & 2 & 2 & 1 & 2 & 1 & 2 & 2 & 2 & 1 \\
\hline 23,5 & & 1 & 1 & 1 & 1 & 2 & 1 & 3 & 2 & 1 \\
\hline 24,5 & - & 1 & 1 & 1 & 1 & 3 & 1 & 4 & 1 & 1 \\
\hline 25,5 & - & 1 & 1 & - & 1 & 3 & 1 & 5 & 1 & 1 \\
\hline 26,5 & - & 1 & 1 & - & 2 & 4 & 1 & 3 & - & 1 \\
\hline 27,5 & - & 1 & 1 & - & 1 & 7 & 1 & 2 & - & 1 \\
\hline 28,5 & - & 1 & 1 & - & 2 & 3 & - & 2 & - & - \\
\hline 29,5 & - & - & - & - & 1 & 2 & - & 1 & - & - \\
\hline 30,5 & - & - & - & - & 1 & 1 & - & - & - & - \\
\hline
\end{tabular}




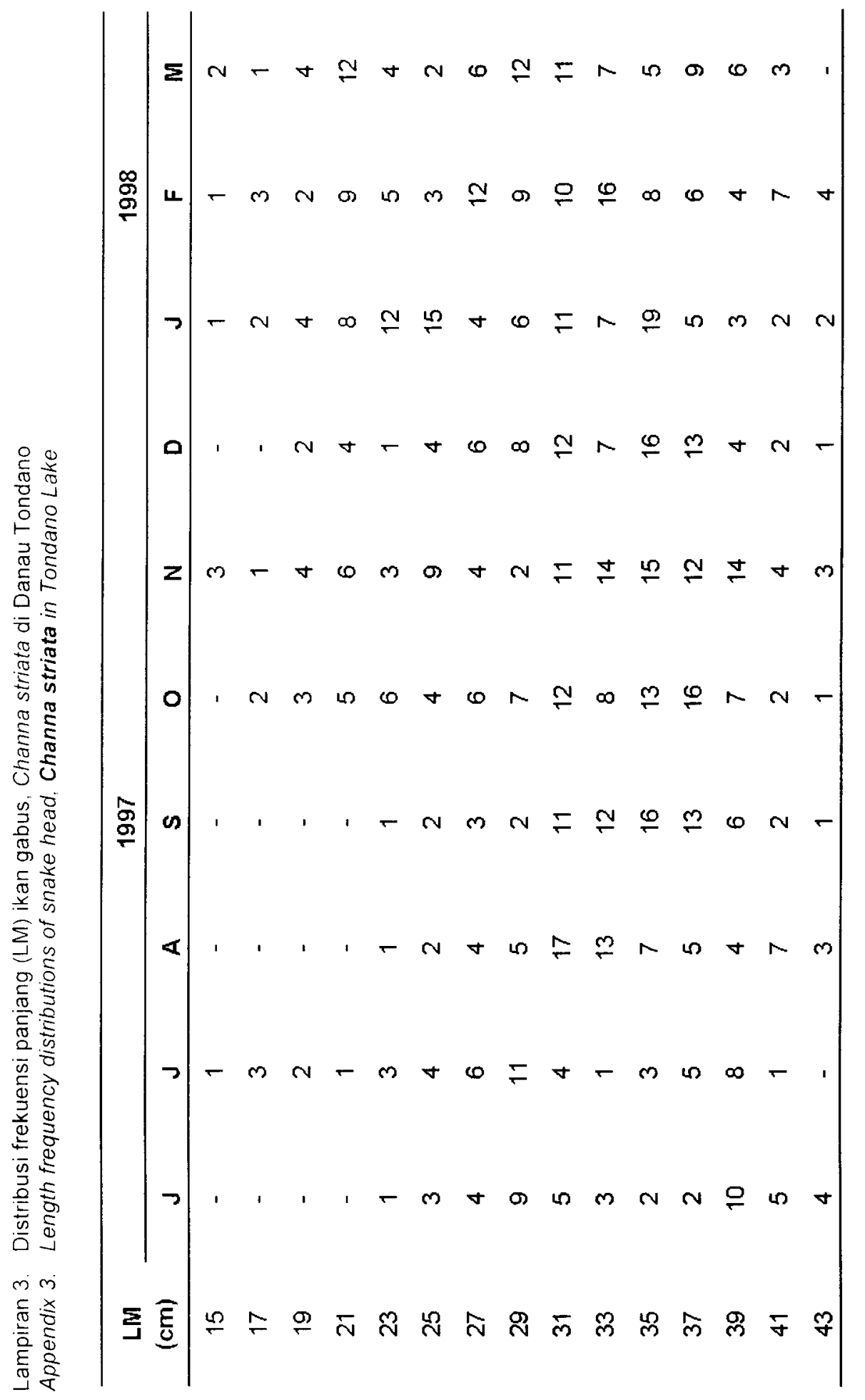

